Rev. Int. Contam. Ambie. 35 (Environmental Engineering of Sustainable Landscapes) 65-71, 2019

DOI: 10.20937/RICA.2019.35.esp01.07

\title{
KITCHEN WASTE SOLID STATE FERMENTATION BY Aspergillus niger TO PRODUCE ACID PROTEASE
}

\author{
Shuai $\mathrm{ZHANG}^{1}$, Hao $\mathrm{CHENG}^{2,3 *}$, Hongxiang $\mathrm{ZHU}^{3,4 * *}$ and Ning $\mathrm{CHEN}^{1}$
}

${ }^{1}$ School of Food \& Pharmaceutical Engineering, Zhaoqing University, Zhaoqing 526061, China

${ }^{2}$ Guangxi Key Laboratory of Green Processing of Sugar Resources, College of Biological and Chemical Engineering, Guangxi University of Science and Technology, Liuzhou 545006, China

3 Institute of Light Industry and Food Engineering, Guangxi University, Nanning 530004, China

${ }^{4}$ Province and Ministry Co-sponsored Collaborative Innovation Center of Sugarcane and Sugar Industry, Nanning 530004, China

*Corresponding Author: hc0229@live.com; ** zhx@gxu.edu.cn

(Received May 2018; accepted July 2018)

Key words: kitchen waste, Aspergillus niger, solid state fermentation, acid protease

\begin{abstract}
Acid protease production was carried out by solid state fermentation (SSF) with $A s$ pergillus niger using kitchen waste as the principal raw material. The SSF conditions were studied and the optimal one was identified. This study explored effects of different water contents in SSF medium, different inoculum sizes and different fermentation time on acid protease activities by following the one-factor-at-a-time method. Based on the results obtained, the optimal fermentation conditions for the production of $\mathrm{c}$ acid protease, were are as follows: $30 \mathrm{~g}$ of kitchen waste content, $20 \mathrm{~mL}$ of initial water content, $4 \mathrm{~mL}$ of inoculum, and $70 \mathrm{~h}$ ofas fermentation time. Under these fermentation conditions, the activity of the acid protease was $223.518 \mathrm{U}$.
\end{abstract}

Palabras clave: desperdicios de cocina, Aspergillus niger, fermentación en estado sólido, proteasa ácida

\section{RESUMEN}

Se llevó a cabo la producción de proteasa ácida por fermentación en estado sólido (SSF, por sus siglas en inglés) con Aspergillus niger, utilizando desperdicios de cocina como principal materia prima. Se estudiaron las condiciones de la SSF y se identificó la óptima. La investigación exploró el contenido de agua en el medio y diferentes cantidades de inóculo y tiempos de fermentación en la actividad de la proteasa ácida con el método de un factor a la vez. Con base en los resultados obtenidos, las conndiciones óptimas de fermentación para la producción de proteasa ácida fueron: $30 \mathrm{~g}$ de desperdicos de cocina, $20 \mathrm{~mL}$ de agua iniciales, $4 \mathrm{~mL}$ de inóculo y $70 \mathrm{~h}$ de tiempo de fermentación. Bajo estas condiciones la actividad de la proteasa ácida fue de $223.518 \mathrm{U}$. 


\section{INTRODUCTION}

Kitchen waste refers to the household wastes left over from household consumption, including the wastes and food residues left over from the food processing in families, restaurants, canteens and various food and beverage industries (Yang et al. 2017, Fu and Liu 2017, Lamas et al. 2016, Ali and Zayan 2017, Wahab and Adzmi 2017). Its main features are as follows: they are perishable, smelly, easy to breed and spread bacteria and viruses, and rich in organic nutrients; their sources are relatively concentrated and obvious, and they have high water content and are easy to be collected (Quan 2011, Sharifuzzaman et al. 2017). Due to the high water content and grease content in the kitchen waste, it is not conducive to incinerate household waste, and the landfill can easily pollute groundwater and generate much biogas, causing secondary pollution to the environment (Borogayary et al. 2018, Albrecht and Shaffer 2016, Khan et al. 2017, Khan et al. 2018). China is a country with large amounts of kitchen waste. Every day, a large amount of kitchen waste is thrown away, which is a waste of resources and polluting the environment. Many processing technologies are currently available, such as crushing disposal, earthworm treatment, organic fertilizer by aerobic fermentation, protein feed by thermophilic fermentation, extraction of biodegradable plastic, biogas production by anaerobic digestion, hydrogen production by biological fermentation (Wang et al. 2004, Yu et al. 1999, Ye et al. 2015, Fu and Liu 2017, Afzal et al. 2018). However, due to various reasons related to funding, siting, technologies and so on, they have yet to be widely used in the country. At present, the main method of treating kitchen waste in China is to throw it away or collect it and then send it to farms as feed. Although this simple feed treatment shows the value of recycling kitchen waste, it is not safe to use it to directly feed livestock due to its homologous pollution (Xu et al. 2011, Ashraf et al. 2017, Anees et al. 2017). Although kitchen waste contains toxic materials, its main components are vegetables, rice noodles, meat, and the like, and its main chemical composition is organic matters such as starch, cellulose, protein and lipid. Therefore, kitchen waste can be reused and recycled. Proper handling of them can deliver benefits to the society, the environment and the economy.

Acid protease is an enzyme that hydrolyzes proteins and polypeptides in acidic environments. Because of its good acid resistance, it is widely used as an important industrial enzyme in feed processing, brewing alcohol and beer, leather technology, and in light industry and food processing industry. People are closely followingwatching the potential of acid protease (Liu et al. 2004, Zhang et al. 2009, Yu et al. 2006, Wang et al. 1993, Mi et al. 2016, Mi et al. 2017, Ali and Iftikhar 2017, Shamsudin et al. 2017). Acid protease is mainly obtained through microbial fermentation currently, which can be generated by Aspergillus niger, Aspergillus oryzae, Bacillus, etc (Shen et al. 1999, Nongqwenga and Modi 2017). Aspergillus niger is the most commonly used fungus for producing acid protease due to it is less toxic and generates more metabolites. Microbial SSF requires fewer investments, and has the advantages of low energy consumption, easy operation, easy promotion, generating less pollution, and having simple post-processing and fermentation process. Microbial SSF also uses simple equipment and can be easily promoted. Aspergillus niger fit falls in the category of SSF filamentous fungi. To produce a large amount of acid protease at low cost so as to meet the market demand has become a vision for many researchers.

Kitchen waste is rich in protein, fat, carbohydrates and many kinds of inorganic salts, and can promote the growth and reproduction of a variety of microbes. Therefore, the fermentation conditions of acid protease, which is produced by Aspergillus niger SSF kitchen waste, were studied, and the optimal conditions were finally worked outidentified. It is expected to provide an example for the integrated use of kitchen waste and the production and preparation of acid protease.

\section{MATERIALS AND METHODS}

\section{Materials and reagents}

Kitchen waste, collected on June 18, 2017 at the restaurant on the first floor of the fourth canteen of Zhaoqing College.

Strain: Aspergillus niger (purchased from Guangdong Culture Collection Center, strain preservation number: CICC2377), Food Microbiology Laboratory of Zhaoqing College.

The main reagents: potato dextrose agar (PDA) medium, Guangdong Huankai Microbial Sci. \& Tech. Co.,Ltd.; foline-phenol reagent, trichloroacetic acid, casein, lactic acid, L-tyrosine, anhydrous sodium carbonate and sodium lactate are of domestic analytical grade.

SSF medium: remove plastic, paper towels and other sundries in the kitchen waste, and then take gauze filter residue. Dry and crush the residue to obtain SSF medium. Take several of 250-ml flasks 
of $250 \mathrm{ml}$, each loaded with $30 \mathrm{~g}$ of medium, and then add due amounts of water according to the design of the experiment. All media were sterilized at $121{ }^{\circ} \mathrm{C}$ for $20 \mathrm{~min}$.

\section{Instruments and equipment}

LRH-150 biochemical incubator; SW-CJ-2FD clean bench; Shimadzu UV-1240 UV-visible spectrophotometer; TDZ5-WS centrifuge; HH-6 digital thermostat water bath; PHS-25 pH meter; DHG9070B digital electric oven; BF-08 small grinder.

\section{Experimental methods}

Measurement of the main components of the medium

(1) Measurement of crude protein content is in accordance with the national standard (GB 5009.5-2010 Kjeldahl method) (GB/T 6432-1994).

(2) Measurement of crude fat content is in accordance with the national standard GB/T 64332006 (Soxhlet extraction method) (GB/T 64332006).

(3) Measurement of starch content is in accordance with the national standard GB/T 5009.9-2008 (acid hydrolysis method) (GB/T 5009.9-2008).

(4) Measurement of water content is in accordance with the national standard GB/T 6435-2014 (direct drying method) (GB/T 6435-2014).

(5) Measurement of crude ash content is in accordance with the national standard GB/T 6438-2007 (high temperature burning method) (GB/T 64382007).

(6) Measurement of cellulose content is in accordance with the national standard GB/T 6434-2006 (filtration method) (GB/T 6434-2006).

\section{Preparation of spore suspension}

Aspergillus niger routinely separated and purified from the plate medium was inoculated on a beveled test tube and incubated at a constant temperature of $30^{\circ} \mathrm{C}$ for 3-5 days until the beveled test tube was covered with spores. Add $10 \mathrm{~mL}$ of sterile water, use glass beads to scatter the spores, and make a spore suspension. Uuse a hemocytometer to count the number of spores and save the spore suspension for future use (Zhang and Zhou 2011, Lin et al. 2014).

\section{SSF enzyme production}

TakeP $30 \mathrm{~g}$ of smashed kitchen waste in a $250-\mathrm{mL}$ Erlenmeyer flask, sterilize the wasteflask at $121^{\circ} \mathrm{C}$ for $30 \mathrm{~min}$, and cool it to room temperature and add the spore suspension to it. Add a certain amount of sterile water, shake up the water and waste in the flaskk, keep them fermented at $30{ }^{\circ} \mathrm{C}$ in a constant temperature incubator, shake them up several times during fermentation to ensure that Aspergillus niger spread evenly in the kitchen waste.

\section{Preparation of crude enzyme solution}

Smash and shake up enzymatic ferments obtained after a certain time of kitchen waste SSF by Aspergillus niger, take $5 \mathrm{~g}$ of such ferments in a triangular flask, add $50 \mathrm{~mL}$ of $1 \% \mathrm{NaCl}$ solution, leach them in water bath at $40{ }^{\circ} \mathrm{C}$ for $30 \mathrm{~min}$, and filter them with gauze and centrifuge to obtain crude enzyme solution (Zhang et al. 2009, Xie et al. 2005).

\section{Measurement of acid protease enzyme activity}

Measurement of acid protease is in accordance with the GB/T 28715-2012 (GB/T 28715-2012)

Drawing of the standard tyrosine curve

Respectively prepare $0.0-\mu \mathrm{g} / \mathrm{mL}, 10.0-\mu \mathrm{g} / \mathrm{mL}$, $20.0-\mu \mathrm{g} / \mathrm{mL}, 30.0-\mu \mathrm{g} / \mathrm{mL}, 40.0-\mu \mathrm{g} / \mathrm{mL}, 50.0-\mu \mathrm{g} /$ $\mathrm{mL}$ and $60.0-\mu \mathrm{g} / \mathrm{mL}$ L-tyrosine standard working solutions. Take $1.0 \mathrm{~mL}$ of each of these solutions, add into these solutions a certain amount of sodium carbonate solution and foline-phenol reagent, and keep these solutions fermented in water bath at $40^{\circ} \mathrm{C}$ for $20 \mathrm{~min}$. Then move these solutions out quickly, cool them to room temperature in cold water, and measure the absorbance at $680 \mathrm{~nm}$ with $10 \mathrm{~mm}$ cuvette. Take L-tyrosine content as the abscissa and the absorbance as the vertical axis. Then a standard curve can be drawn and an equation of linear regression can be obtained.

Definition of the protease activity: the amount of enzyme required to hydrolyze casein into $1 \mu \mathrm{g}$ of tyrosine per minute at a $\mathrm{pH}$ of 3.0 under $(40 \pm 2)^{\circ} \mathrm{C}$ is one unit of measurement of enzyme activity. The measurement is carried out according to the folinephenol method, and a unit of measurement of enzyme activity is expressed in $\mathrm{U}$.

Acid protease enzyme activity formula:

$\mathrm{X}_{\mathrm{i}}=\mathrm{c} \times \mathrm{V} \times 4 \times \mathrm{N} /(1.0 \times \mathrm{m} \times 10)$

Where: $\mathrm{X}_{\mathrm{i}}$ is the protease activity $(\mathrm{U})$; $\mathrm{c}$ is the tyrosine concentration $(\mu \mathrm{g} / \mathrm{mL})$ obtained from the standard curve;

$\mathrm{V}$ is the total volume of the extract $(\mathrm{mL}) ; 4$ is the total volume of enzyme reaction $(\mathrm{mL})$;

$\mathrm{N}$ is the second dilution times of the sample extract; 1.0 is the amount of enzyme $(\mathrm{mL})$; involved in the reaction;

$\mathrm{m}$ is the sample's mass $(\mathrm{g}) ; 10$ is the reaction time (min) 
TABLE I FERMENTATION MEDIUM (KITCHEN WASTE) COMPOSITION

\begin{tabular}{lcccccc}
\hline Item & Protein & Starch & Fat & Cellulose & Moisture & Ash content \\
\hline Content $/ \%$ & 15.26 & 36.95 & 14.67 & 6.72 & 11.30 & 8.41 \\
\hline
\end{tabular}

\section{Acid protease separation (salting-out method)}

Filter and centrifuge the crude enzyme solution, add into the solution solid ammonium sulfate until reaching the saturation point. After one whole night, remove the supernatant and dry the solid precipitated by the filter press at $40{ }^{\circ} \mathrm{C}$ for $24 \mathrm{~h}$. After drying and pulverizing, the crude enzyme product is obtained (Zheng 2006).

\section{RESULTS AND ANALYSIS}

\section{Composition of the fermentation medium (kitchen waste)}

Table I shows that the main components of kitchen waste are protein, starch and fat-based organic matters, which can promote the growth and reproduction of a variety of microbes and can be used to breed Aspergillus niger.

\section{Drawing of standard tyrosine curve}

The standard curve drawn according to the method of 1.4.7 is shown in Fig. 1, and the regression equation is obtained: $\mathrm{y}=0.0106 \mathrm{x}+0.0021, \mathrm{R}^{2}=0.9999$.

\section{Single-factor experiment of fermentation condi- tions \\ The experiment identified the optimal inoculum size, fermentation time and water holding capacity for using kitchen waste SSF by Aspergillus niger to produce acid protease.}

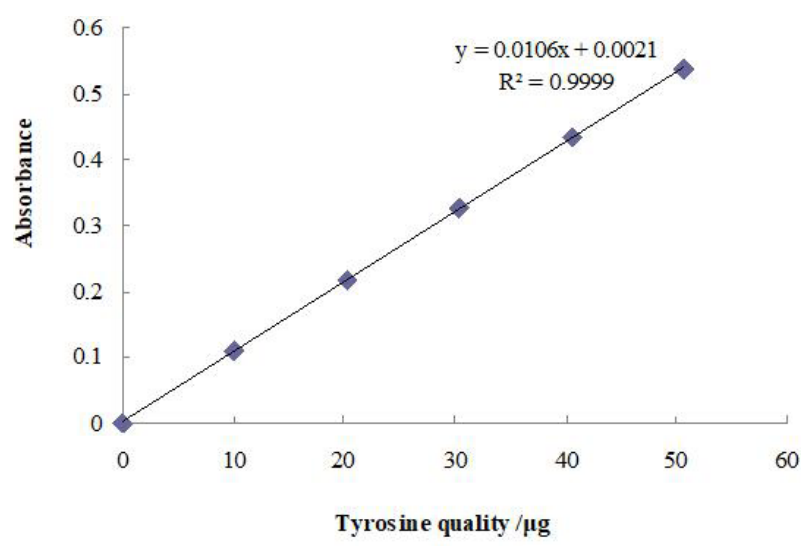

Fig. 1. Standard tyrosine curve

\section{Effects of different inoculum sizes on the enzyme production}

Respectively add into the kitchen waste solid medium 1, 2, 3, 4, 5, 6, 7 and $8 \mathrm{~mL}$ of spore suspension whose spore concentration is $2.5 \times 10^{6}$. Keep these solutions fermented in a $30{ }^{\circ} \mathrm{C}$-biochemical incubator for $70 \mathrm{~h}$. Effects of different inoculum sizeson enzyme production were studied. The results are shown in Fig. 2. When the inoculum size was under $3 \mathrm{~mL}$, increase of inoculum could promote the production of enzyme, and when above $3 \mathrm{~mL}$, increase of inoculum does not make much difference to enzyme production.

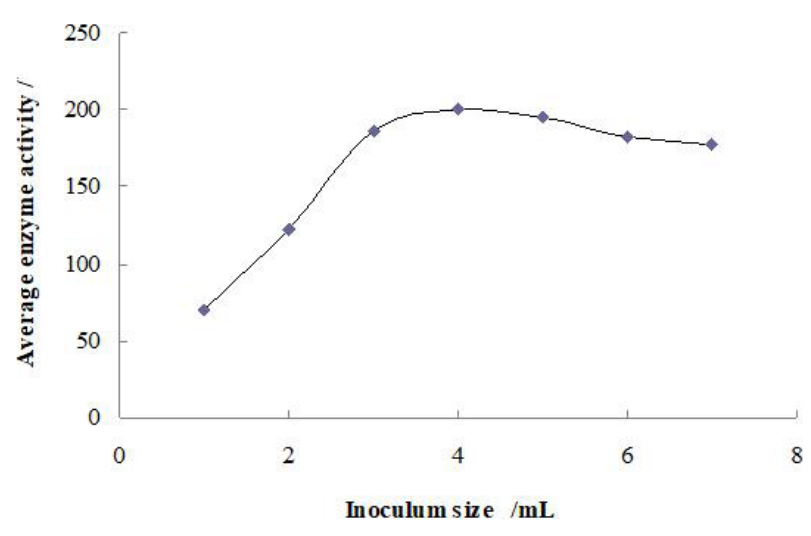

Fig. 2. Effects of different inoculum sizes on enzyme production.

\section{Effects of different water contents on the enzyme production}

Water content in the medium determines the growth and reproduction of Aspergillus niger. Too little water does harm to the growth of Aspergillus niger cells. Too high will inhibit its normal life activity. Respectively add into $4 \mathrm{~mL}$ of inoculum and $30 \mathrm{~g}$ of kitchen waste solid medium 5, 10, 15, 20, 25 and $30 \mathrm{~mL}$ of sterile water. Then study the effects of different water contents on the production of enzymes. The results are shown in Fig. 3. The maximum amount of enzyme produced was $20 \mathrm{~mL}$. When the amount of water added was higher or lower than $20 \mathrm{~mL}$, the amount of enzyme produced decreased remarkably. Water content had a significant effect on the production of enzyme. 


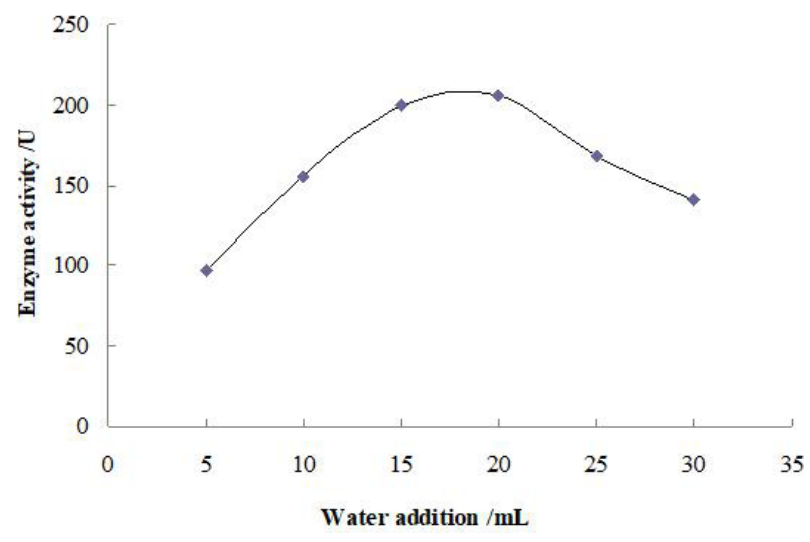

Fig. 3. Effects of different water contents on the production of enzymes

\section{Effects of different fermentation time spans on the production of enzymes}

The fermentation time span is one of the key factors in the production of acid protease. In the pre-fermentation stage, the activity of producing acid protease by Aspergillus niger increases with the growth and reproduction of bacterial cells, and the protease may be consumed in the late fermentation stage. $4 \mathrm{~mL}$ of spore suspension, $30 \mathrm{~g}$ of kitchen waste solid medium, and $20 \mathrm{~mL}$ of sterile water were mixed up and fermented for respectively 40, 50, 60, 70, 80 and $90 \mathrm{~h}$. The protease activity was measured, and the curve was obtained, as shown in Fig. 4. The figure shows that the enzyme activity increased rapidly within $70 \mathrm{~h}$ of culture, and a slight decrease in enzyme activity is observed after $70 \mathrm{~h}$.

\section{Identify the optimal fermentation conditions by using orthogonal experiments}

The best fermentation conditions of the culture medium are not simply the optimal superposition

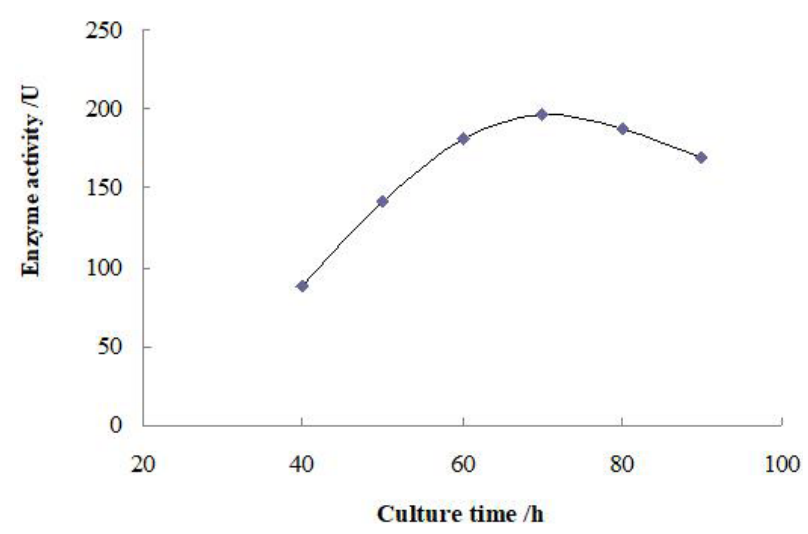

Fig. 4. Effects of different fermentation time spans on the production of enzymes. of each single factor. Interaction exists between the various conditions. When these conditions interact properly, Aspergillus niger can better facilitate growth and metabolism of enzymes. The three-factor and three-level orthogonal experiment on different inoculum sizes, water contents, culture time spans is shown in Table II, aiming to further find out the optimal culture conditions and to identify the optimal conditions for enzyme production.

TABLE II. ORTHOGONAL TEST DESIGN TABLE OF CULTURE CONDITIONS.

\begin{tabular}{lccc}
\hline Level & \multicolumn{3}{c}{ Factor } \\
\cline { 2 - 4 } & $\begin{array}{c}\text { A(Culture } \\
\text { time span } / \mathrm{h})\end{array}$ & $\begin{array}{c}\mathrm{B}(\text { Water } \\
\text { content } / \mathrm{mL})\end{array}$ & $\begin{array}{c}\mathrm{C}(\text { Inoculum } \\
\text { size } / \mathrm{mL})\end{array}$ \\
\hline 1 & 65 & 18 & 3 \\
2 & 70 & 20 & 4 \\
3 & 75 & 22 & 5 \\
\hline
\end{tabular}

As can be seen from Table III, the optimal formula for producing enzymes is $\mathrm{A}_{2} \mathrm{~B}_{2} \mathrm{C}_{2}$ : $70 \mathrm{~h}$ of culture time, $20 \mathrm{~mL}$ of water, and $4 \mathrm{~mL}$ of inoculum.

\section{Extraction and separation of acid protease}

According to the optimal formula, mix up $20 \mathrm{~mL}$ of water, $4 \mathrm{~mL}$ of spore suspension and $30 \mathrm{~g}$ of kitchen

TABLE III. L L $_{9}\left(3^{4}\right)$ ORTHOGONAL EXPERIMENTAL RESULTS AND ANALYSIS

\begin{tabular}{|c|c|c|c|c|c|}
\hline \multirow[t]{2}{*}{$\mathrm{S} / \mathrm{N}$} & \multicolumn{4}{|c|}{ Factor } & \multirow{2}{*}{$\begin{array}{l}\text { Enzyme } \\
\text { activity (U) }\end{array}$} \\
\hline & A & B & $\mathrm{C}$ & $\begin{array}{l}\text { Nullable } \\
\text { column }\end{array}$ & \\
\hline 1 & 1 & 1 & 1 & 1 & 167.132 \\
\hline 2 & 1 & 2 & 2 & 2 & 186.755 \\
\hline 3 & 1 & 3 & 3 & 3 & 179.585 \\
\hline 4 & 2 & 1 & 2 & 3 & 201.849 \\
\hline 5 & 2 & 2 & 3 & 1 & 204.113 \\
\hline 6 & 2 & 3 & 1 & 2 & 198.830 \\
\hline 7 & 3 & 1 & 3 & 2 & 180.717 \\
\hline 8 & 3 & 2 & 1 & 3 & 185.623 \\
\hline 9 & 3 & 3 & 2 & 1 & 178.453 \\
\hline $\mathbf{K}_{1}$ & 1.420 & 1.463 & 1.468 & 1.463 & \\
\hline $\mathbf{K}_{2}$ & 1.609 & 1.534 & 1.509 & 1.507 & \\
\hline $\mathbf{K}_{3}$ & 1.450 & 1.482 & 1.502 & 1.509 & \\
\hline $\mathrm{k}_{1}$ & 0.473 & 0.488 & 0.489 & 0.488 & \\
\hline $\mathrm{k}_{2}$ & 0.536 & 0.511 & 0.503 & 0.502 & \\
\hline $\mathrm{k}_{3}$ & 0.483 & 0.494 & 0.501 & 0.503 & \\
\hline $\mathrm{R}$ & 0.063 & 0.024 & 0.014 & 0.015 & \\
\hline
\end{tabular}


waste solid medium. After $70 \mathrm{~h}$ of culture at $30^{\circ} \mathrm{C}$, carry out the experiments of the acid protease extraction and separation. Measure the acid protease activity of the crude enzyme solution obtained according to the optimal formula and the dried crude enzyme product. The acid protease activity of the crude enzyme solution and the crude enzyme product were respectively $223.518 \mathrm{U}$ and 2954.74 U. Crude enzyme products obtained through the salting-out method contain a large amount of impurities, and to obtain more active acid protease products, further separation and purification are needed.

\section{CONCLUSION}

Kitchen waste is rich in various nutrients that can promote the growth and reproduction of a variety of microbes and is a good raw material for microbial fermentation. Using kitchen waste to produce acid protease not only can generate more active enzymes, but also can better utilize kitchen waste and deliver benefits to the society, environment and economy. Single-factor experiment and orthogonal experiment have identified the optimal conditions for producing the enzyme: mix up $20 \mathrm{~mL}$ of sterile water, $30 \mathrm{~g}$ of kitchen waste SSF medium, and $4 \mathrm{~mL}$ of suspension of Aspergillus niger whose spore concentration is $2.5 \times 10^{6}$, and keep them fermented for $70 \mathrm{~h}$ under constant temperature of $30^{\circ} \mathrm{C}$. Under such culture conditions, the crude enzyme activity of acid protease reaches up to $223.518 \mathrm{U}$, indicating that using kitchen waste SSF by Aspergillus niger can produce more active acid protease.

This is just a preliminary experiment on the kitchen waste SSF technique. However, to use this technique in our daily life, it is necessary to experiment with the Aspergillus niger strain, medium supplement, culture temperature and the like. The obtained fermentation products and crude enzyme products also need further analysis.

\section{ACKNOWLEDGMENTS}

This work is funded by the Key Laboratory for the Processing of Sugar Resources of Guangxi Higher Education Institutes (2016TZYKF01), Guangxi Major Projects of Science and Technology (Grant No. GXMPSTAA18118013) and the High Level Innovation Team and the Excellent Scholars Program in colleges of Guangxi.

\section{REFERENCES}

Afzal M.N.I., Lawrey R., Anaholy M.S. and Gope J. (2018). A Comparative Analysis of The Efficiency and Productivity of Selected Food Processing Industries in Malaysia. Malaysian Journal of Sustainable Agriculture. 2(1), 19-28.

Albrecht F., and Shaffer G. (2016). Regional Sea-Level Change along the Chilean Coast in the 21st Century. Journal of Coastal Research. 32 (6), 1322-1332.

Ali S., Ali R. and Iftikhar A. (2017). Physico-chemical and microbiological assessment of some freshwater aquifers and associated diseases in district ghizer, gilgit-baltistan, Pakistan. Acta Scientifica Malaysia. 1(1), 08-12.

Ali S.M.M. and Zayan J.M. (2017). Drag Reduction for A Fast Back Passenger Car (Logan). Science Heritage Journal. 1(2), 17-20.

Anees M.M., Qasim M. and Bashir A. (2017). Physiological and Physical Impact of Noise Pollution on Environment. Earth Science Pakistan. 1(1), 08-11.

Ashraf M.A., Hussin N.H. and Gharibreza M. (2017). Studies on the Removal of Heavy Metals from Aqueous Solution Using Immobilized Typha angustata L. Earth Science Pakistan. 1(1), 12-16.

Borogayary B., Das A.K. and Nath A.J. (2018). Tree species composition and population structure of a secondary tropical evergreen forest in Cachar district, Assam. Journal of Environmental Biology. 39 (1), 67-71.

Fu H., Liu X. (2017). Research on the Phenomenon of Chinese Residents' Spiritual Contagion for the Reuse of Recycled Water Based on SC-IAT. Water 9 (84611). doi: 10.3390/w9110846.

Fu H.L. and Liu X.J. (2017). Research on the Phenomenon of Chinese Residents' Spiritual Contagion for the Reuse of Recycled Water Based on SC-IAT. Water, 9 (11), 846 .

GB/T 28715-2012. (2012). Feed additives - Determination of Acid and Neutral Protease Activity in Feed Additives - Spectrophotometric Method. Beijing: Standards Press of China.

GB/T 5009.9-2008. (2008). Determination of Starch in Foods. Beijing: Standards Press of China.

GB/T 6432-1994. (2009). Determination of Crude Protein in Feeds. Beijing: Standards Press of China.

GB/T 6433-2006. (2006). Determination of Crude Fat in Feeds. Beijing: Standards Press of China.

GB/T 6434-(2006). Determination of Crude fiber in Feeds - Filtration Method. Beijing: Standards Press of China.

GB/T 6435-2014. (2014). Determination of Moisture in Feeds. Beijing: Standards Press of China.

GB/T 6438-2007. (2007). Determination of Crude Ash in Feeds. Beijing: Standards Press of China. 
Khan A.M., Yusoff I., Abu Bakar N.K., Abu Bakar A.F., Alias Y. and Mispan M.S. (2017). Accumulation, uptake and bioavailability of rare earth elements (rees) in soil grown plants from ex-mining area in perak, malaysia. Applied Ecology and Environmental Research, 15 (3), 117-133.

Khan F., Khan M.I., Khan S., Zaman M.A.U., Rasheed H. and Khan A.R. (2018). Evaluation of Agronomic Traits for Yield and Yield Components in Wheat Genotypes with Respect To Planting Dates. Malaysian Journal of Sustainable Agriculture. 2(1), 7-11.

Lamas M.I., Rodriguez C.G., Rodriguez J.D. and Telmo J. (2016). Numerical Model of So2 Scrubbing with Seawater Applied to Marine Engines. Polish Maritime Research, 23 (2), 42-47.

Lin J.H., Xiao H. and Ma S.H. (2014). Verification of Shelf Life of Aspergillus niger Spore Suspension. Drug Standards of China, 15 (2), 117-119.

Liu X., Li J. and Liu K.W. (2004). Catalytic Effect of Aspergillus niger Acid Protease in Vinegar Brewing. Chemical Research and Application, 16 (4), 482-484.

Mi C., Shen Y., Mi W.J. and Huang Y.F. (2015). Ship Identification Algorithm Based on 3D Point Cloud for Automated Ship Loaders. Journal of Coastal Research, (73), 28-34.

Mi C., Zhang Z.W. and Huang Y.F. (2016). A Fast-Automated Vision System for Container Corner Casting Recognition. Journal of Marine Science and Technology, 24 (1), 54-60.

Nongqwenga N., and Modi A.T. (2017). Phosphorus and Potassium Quantity/Intensity Properties of Selected South African Soils (Kwazulu-Natal) and Their Correlation with Selected Soil Parameters. Applied Ecology and Environmental Research, 15 (3), 1-14.

Quan J.X. (2011). Resourceized Disposal and Comprehensive Utilization of Urban Kitchen Waste. Technology Innovation and Productivity, 214, 69-73.

Shamsudin S.B., Marzuki A., Jeffree M.S. and Lukman K.A. (2017). Blood lead concentration and working memory ability on malay primary school children in urban and rural area, Malacca. Acta Scientifica Malaysia. 1(1), 04-07.

Sharifuzzaman M.D., Lemckert C.D. and Etemad-Shahidi A. (2017). Dynamics of lock-release crystalline gravity currents. Geology, Ecology, and Landscapes, 1(4), 213-218.
Shen P., Fan X.R. and Li G.W. (1999). Microbiology Experiment. Beijing: Higher Education Press, 214-215.

Wahab W.A. and Adzmi A.N. (2017). The Investigation of Cytotoxic Effect of Cinnamomum Zeylanicum Extracts on Human Breast Cancer Cell Line (Mcf-7). Science Heritage Journal. 1(2), 21-26.

Wang Q.H., Ma H.Z. and Wang X.M. (2004). Recycling Technology of Kitchen Waste. Modern Chemical Industry, 24 (7), 56-59.

Wang X.G., Zhang A.Q. and Yu L.P. (1993). Study on the Application of Acid Protease in Soy Sauce Brewing. Biotechnology, 3 (4), 26-29+21.

Xie B.F., Cao Z.Y. and Zheng T. (2005). Purification and Characterization of Acid Protease from Aspergillus niger SL2-111. Chinese Journal of Applied and Environmental Biology, 11 (5), 618-622.

Xu C.Y., Song W. and Zhao S.Q. (2011). Study on Homologous Pollution of Kitchen Waste Feed Processing Technology. Environmental Sanitation Engineering, 19 (1), 9-10.

Yang A., Han Y., Pan Y., Xing H. and Li J. (2017). Optimum surface roughness prediction for titanium alloy by adopting response surface methodology. Results in Physics 7, 1046-1050. doi: 10.1016/j.rinp.2017.02.027.

Ye Q.X., Wei X.L. and Lin L.Y. (2015). Process Plan for Resourceized Utilization of Kitchen Waste. China Environmental Protection Industry, (10), 42-45.

Yu C.Z., Dong X.K. and Wang Q.J. (2006). Study on the Effect of Acid Protease 537 on Leather Extensibility of Sheep Wet Blue. China Leather, 35 (9), 16-20+25.

Yu P.H., Chua H. and Huang A.L. (1999). Transformation of industrial food wastes into polyhydroxyalkanoates. Water Science and Technology, 40 (1), 365-370.

Zhang A.M. and Zhou H.T. (2011). Guide Book for Food Science and Engineering Experiment Internship. Beijing: Beijing Normal University Press, 19-21.

Zhang X.F., Liu D.Y. and Xia H. (2009). Application of Acid Protease in Sweet Rice Wine Production. China Brewing, (2), 22-124.

Zheng B.D. (2006). Food Enzymology. Nanjing: Southeast University Press, 18-19. 